\title{
Early Assistance in Pre-school Educational Institution: Social and Pedagogical Approach
}

\author{
T. S. Dorokhova \\ Department of Pedagogy \\ Ural State Pedagogical University \\ Yekaterinburg, Russia \\ 70571@mail.ru \\ Yu. N. Galaguzova \\ Department of Pedagogy \\ Ural State Pedagogical University \\ Yekaterinburg, Russia \\ yung.ektb@mail.ru
}

\author{
Yu. A.Verkhoturova \\ Department of Pedagogy \\ Ural State Pedagogical University \\ Yekaterinburg, Russia \\ yula15118@mail.ru \\ M. A. Galaguzova \\ Department of Pedagogy \\ Ural State Pedagogical University \\ Yekaterinburg, Russia \\ gala_36@mail.ru
}

\author{
I. V. Volgina \\ Department of Foreign Languages \\ Ural state medical university Russia \\ Yekaterinburg, Russia \\ volgina7@gmail.com
}

\begin{abstract}
The article is devoted to the possibilities of implementing early assistance for a disabled child or a child with limited abilities (from 0 to 3 years), as well as his parents or persons replacing them in a preschool educational institution. Studies show that the earlier the children of this category begin to provide specialized complex (medical-social, psychological and psychological) assistance, the greater the chances of developing their qualities necessary for successful positive socialization. It is extremely important that such assistance must be provided systematically, regularly. Therefore, it is necessary to prepare parents or individuals from substitutes for mastering the main methods of early help. Due to the relevance of this activity in Russia and abroad in recent years, the number of institutions implementing this activity has increased significantly. Federal and regional documents regulating it have been developed in our country. Basically, baby houses and rehabilitation centers become basic sites for the implementation of early care. However, such institutions are far from being in all settlements of Russia, which significantly limits the possibility of providing early assistance to all needy children and their parents. In this regard, in our opinion, preschool educational institutions have high potential. The article discusses the opportunities and risks for the development of the system of early assistance on the basis of preschool educational institutions on the example of the Municipal preschool educational institution Kindergarten "Romashka" of the Soviet city of the Tyumen region of the Khanty-Mansiysk Autonomous okrug.
\end{abstract}

Keywords - early care, socio-pedagogical approach, pre-school education institution, children with special educational needs, disabled children, abilitation, inclusion, inclusive culture, socialization.

\section{INTRODUCTION}

The system of early assistance in Russia has been developing for almost twenty years. However, the creation of platforms for the provision of targeted medical-social and psychological-pedagogical assistance to disabled children and children with disabilities started only in 2016. Then the Concept of the development of early assistance in the Russian Federation for the period up to 2020 was adopted, approved by the decree of the Government of the Russian Federation of August 18, 2016 No. 426n "On approval of the technical task of the pilot project to develop approaches to the formation of a system of comprehensive rehabilitation and abilitation of the disabled people, including disabled children". In accordance with this Concept, early help services should be created in the constituent entities of the Russian Federation, based on the interaction of social authorities (health, education, and social services) with organizations providing early help services. Regulatory documents and guidelines for creating such services have been developed at the regional level.

However, in spite of all this, such services are virtually absent in preschool education institutions. Meanwhile, many institutions have created conditions for implementing inclusive education, in which all children, regardless of their 
characteristics (including developmental challenges), are included in the general education system and socialize with their peers. It is in this environment that children will get at the next stage of socialization [1]

Pre-school educational institutions are initially aimed at creating conditions for a child to learn social experience and his successful positive self-realization i.e. carry out educational activities on the basis of the socio-pedagogical approach.

The socio-pedagogical approach consists in resolving personality problems based on using the potential of society:

- by including a person in socially significant activities, in new social relations;

- by shaping social needs, developing social abilities and establishing business interaction with social institutions;

- by solving problems in socialization of the current and chronic properties.

The socio-pedagogical approach helps to overcome the narrow departmental view of a personality and its formation in pedagogical science and practice in relatively closed pedagogical (educational) structures (kindergarten, school, institution of additional education, university). It considers its structural and functional relations as a priority in the system of pedagogically regulated educational and upbringing influences [2].

It should also be noted that preschool teachers have a high psychological and pedagogical potential for organizing interaction with the parents of disabled children and children with disabilities [3]. At the same time, most researchers of early childhood problems pay attention to the fact that interaction with parents is the main condition for successful socialization of a young child [4-6].

All this allows us to consider pre-school educational institutions as promising areas for the creation of early help services.

It should be noted that in modern Russian pedagogical science, the issue of organizing early care services on the basis of preschool educational institutions with a socio-pedagogical approach as the main one has not been studied enough. This is due, first of all, to the novelty of the problem under consideration for Russian theory and practice, which in turn actualizes the study of foreign experience.

Since the mid-1990s, a preventive approach has emerged in European socio-pedagogical practice, according to which the priority in the work of early care services was given to preventing the occurrence of a problem, and not its correction.

In this context, early care was seen as an interdisciplinary complex of technologies aimed at preventing or minimizing the physical, cognitive, emotional or resource limitations of children with biological or social risk factors and their families.
At the beginning of the XXI century, the principle of family-centeredness was established in the implementation of early care. It begins to be seen as a system created to support family patterns of interaction that are most conducive to the development of the child [7]. This position actually allows you to implement early care based on a socio-pedagogical approach.

In Russia today, both medical (correctional) and sociopedagogical (family-centered) models for the implementation of early care coexist. Researchers note the advantages and disadvantages of these models $[8,9]$. The unanimity of views on this issue has not been achieved. Although in recent years, extremely interesting discussions have been conducted in social-pedagogical science [10-13]. At the same time, as mentioned above, the degree of knowledge of the problems of organizing early care on the basis of preschool educational institutions remains low.

The above indicates the relevance of the issues raised in the article.

\section{MATERIALS AND METHODS}

As a basic platform for the creation of early help services most often become institutions of public health and social protection of the population. Thus, in the Tyumen region, a network of such services was created on the basis of twenty integrated social service centers for the population, two social rehabilitation centers for underage and an autonomous social service institution for the population, the «Regional Center for the Rehabilitation of the Disabled». Despite the systematic, efficient operation of these institutions, early help services cannot be provided to all in need.

In addition, in services created on the basis of health, education and social services, the emphasis in the implementation of early assistance programs is on medical and social rehabilitation. Often there are not enough specialists such as teachers who carry out social and educational activities during the subsequent periods of child socialization in educational institutions. This does not allow to ensure continuity in the socialization of disabled children and children with disabilities, to implement a socio-pedagogical approach in working with parents. Note that the sociopedagogical approach, in the opinion of domestic researchers, makes it possible to explore from a pedagogical point of view and solve problems in various spheres of social practice: social education and training, social support for the family and child protection, preventive, remedial and rehabilitation and protective and guarding work with various categories of children and adults [14].

The resolution of these contradictions is possible on the condition that early help services are organized on the basis of a socio-pedagogical approach based on preschool educational institutions.

The above actualizes the problem of the presented research. 
Based on the foregoing, the question arises - how to organize an early care service on the basis of a pre-school educational institution. The presented research was conducted on the basis of the Municipal autonomous preschool educational institution Kindergarten "Romashka" in the city of Sovetsky of the Tyumen region of the Khanty-Mansiysk autonomous okrug. To answer the above question, we studied the resources available in the institution for the implementation of the activity in question. In turn, the study of these resources is possible, thanks to the analysis of the projects implemented earlier and being implemented at the given moment in the MAPEI (Municipal autonomous preschool educational institution) Kindergarten "Romashka":

- «Alenkyi Tsvetochek» (2012-2015 yy.);

- «Here lives the good»(2016-2017 yy.);

- «We know where the good lives» (2017-2018 yy.).

Early help is a family-oriented complex psychologicalpedagogical and medical-social assistance to children of infancy and early age, who have been found to have abnormalities in the development of various functions or deviations from them, as well as the risks of their occurrence at an older age and families in crisis raising such children [8]. Early care is implemented through a system of habilitation measures (medical and social measures aimed at adapting a young child with disabilities and limited abilities to life in society) [15]. For the organization of the service of early care, it is necessary to create certain conditions in the pre-school educational institution, in particular, personnel, material, technical and informational. In this regard, the purpose of this study is to determine the degree of readiness and the potential for creating an early help service and implementing abilitation activities on the basis of the Municipal autonomous preschool educational institution Kindergarten "Romashka" in the city of Sovetsky of the Tyumen region of the Khanty-Mansi Autonomous okrug.

Achieving this goal is possible under the condition that the following tasks are accomplished:

- analysis of human resources (availability, level of competence of teachers and specialists);

- study of material and technical resources necessary for carrying out habilitation measures with children with disabilities and children with limited abilities;

- identification of information resources, including those necessary for raising the level of awareness of teachers, administration, parents on issues of early care.

The following methods were chosen for the study:

- analysis of documents: standards governing the implementation of early assistance in the Tyumen region of the Khanty-Mansi Autonomous okrug, as well as projects implemented earlier and being implemented at the moment in the Kindergarten "Romashka" MAPEI;

- survey methods (teacher survey).
The activities of early care services in the Tyumen Oblast of the Khanty-Mansiysk Autonomous okrug are implemented as part of a tripartite interdepartmental agreement between the Department of Social Development, the Department of Health and the Department of Education and Science based on such documents as:

- the order of interaction of health care institutions and social services of the population of Tyumen in the identification and medical and social support of young children with developmental and health disorders;

- the order of interaction of medical and social services for children early care.

The analysis of these documents revealed that the main areas of work of the early help service are:

- counseling parents on medical rehabilitation issues;

- development and correction of individual course of medical and social abilitation for children;

- organizing and conducting therapeutic and recreational activities (massage, physiotherapy, adaptive physical culture, physiotherapy);

- teaching family members of the child the basics of social and medical rehabilitation at home;

- social medical patronage of the family;

- rendering speech therapy.

\section{RESULTS}

It can be seen from the above list that the focus in the activities of early care services is on the medical and social direction, while the psychological and pedagogical work is not sufficiently implemented. 80 respondents took part in the questionnaire - teachers and employees in the Kindergarten "Romashka" MAPEI. As a result of the survey following contradiction were revealed. On the one hand, the majority of respondents are aware of the importance of the implementation of early assistance, believe that on the basis of the preschool educational institution in which they work there are material and technical resources for the implementation of this activity. On the other hand, the respondents demonstrated unavailability for the implementation of this activity. The survey results are shown in the table below. 
TABLE I. RESULTS OF TEACHER SURVEY IN THE KINDERGARTEN "ROMASHKA"

\begin{tabular}{|c|c|c|}
\hline Question & Possible answer & \% respondents \\
\hline $\begin{array}{l}\text { Do you know what early } \\
\text { care services do }\end{array}$ & Yes & $85 \%$ \\
\hline $\begin{array}{l}\text { Do you think early help } \\
\text { services are needed }\end{array}$ & Yes & $100 \%$ \\
\hline \multirow[t]{3}{*}{$\begin{array}{l}\text { List the areas of early care } \\
\text { services you are aware of }\end{array}$} & $\begin{array}{l}\text { Medical manipulations } \\
\text { (massage) }\end{array}$ & $73 \%$ \\
\hline & Parent Counseling & $85 \%$ \\
\hline & $\begin{array}{l}\text { Educational activities } \\
\text { with children }\end{array}$ & $62 \%$ \\
\hline \multirow{3}{*}{$\begin{array}{l}\text { What specialists do you } \\
\text { think should provide early } \\
\text { care }\end{array}$} & Health care providers & $75 \%$ \\
\hline & $\begin{array}{l}\text { Social educators and } \\
\text { social workers }\end{array}$ & $45 \%$ \\
\hline & Teachers & $43 \%$ \\
\hline \multirow{3}{*}{$\begin{array}{l}\text { In your opinion, on the } \\
\text { basis of which institutions } \\
\text { should early care services } \\
\text { be established }\end{array}$} & Medical & $73 \%$ \\
\hline & Social & $45 \%$ \\
\hline & Educational & $43 \%$ \\
\hline \multirow{2}{*}{$\begin{array}{l}\text { Can early care services be } \\
\text { established on the basis of } \\
\text { pre-school educational } \\
\text { institutions }\end{array}$} & Yes & $54 \%$ \\
\hline & $\begin{array}{l}\text { Only in case special } \\
\text { conditions } \\
\text { are created here }\end{array}$ & $34 \%$ \\
\hline \multirow{3}{*}{$\begin{array}{l}\text { Do you think your } \\
\text { educational institution is } \\
\text { ready for early care }\end{array}$} & Yes & $43 \%$ \\
\hline & No & $46 \%$ \\
\hline & Partly & $11 \%$ \\
\hline \multirow[t]{3}{*}{$\begin{array}{l}\text { Are you ready for early } \\
\text { care }\end{array}$} & Yes & $11 \%$ \\
\hline & No & $64 \%$ \\
\hline & $\begin{array}{l}\text { Only with advanced } \\
\text { training }\end{array}$ & $25 \%$ \\
\hline
\end{tabular}

Analysis of the documents available in MAPEI showed that, starting from 2012, an activity on creating an inclusive environment has been carried out, there are general developmental and remedial groups that are attended by disabled children and children with limited abilities; assistance is provided to children with severe complex developmental disorders at home. The publication of the authors was devoted to the analysis of the projects implemented here:

- «Alenkyi Tsvetochek»;

- «Here lives the good» [16].

As a result, it was revealed that for the period from 2012, the Kindergarten "Romashka" MAPEI created the material and technical base necessary for the implementation of inclusive education, which can also be used in the implementation of early care programs.

\section{DISCUSSION}

The results of the study showed that on the basis of the Kindergarten "Romashka" MAPEI, the city of Sovetsky can provide early assistance to children with disabilities and children with disabilities, as well as constructive interaction with their parents. Moreover, this activity is extremely in demand and will allow one to more effectively implement this activity in the region.

However, this requires a number of conditions.

First, to solve the personnel problem. To do this, all teachers of MAPEI must undergo advanced training courses for early care. Speech therapists, psychologists, music leaders, physical education instructors, and an additional education teacher must receive special training in advanced practiceoriented first aid programs. Special training is also required for administrators who will serve as the head of the service, his deputy and coordinator.

In addition, it is necessary to establish close contacts with the health care institutions of the city of Sovetsky in order to include medical specialists (pediatrician, pediatric neurologist, child psychiatrist, exercise therapy doctor, ophthalmologist, audiologist, deaf technologist) into the early care program.

Second, to develop an early care program aimed at solving the following tasks:

- creating a single psychologically safe, developing and (inclusive) environment for various categories of children;

- ensuring that the features of early development are taken into account (the diagnosis of the level of development and adaptation that is relevant for each age stage, the identification of the child's potential opportunities and needs);

- organization of an effective psychological and pedagogical support system for a family raising a disabled child or a child with limited abilities;

- organization of the work of specialists in the framework of medical, social, psychological and pedagogical activities, taking into account the structure of the child's primary defect for the protection and strengthening of his physical and neuromental health;

- ensuring the experience of positive psychologically comfortable interaction with the subjects of the educational process [17].

The main types of work with the child and his family in the framework of the program being developed are: individual and group classes with the child and parents, counseling (both in the institution and at home), as well as training for parents. In turn, occupations with a child of a correctionaldevelopmental orientation may include activities for the development of speech, fine motor skills, game therapy, 
classes with modular equipment, using the methods of Montessori-pedagogy and sand therapy.

Among the functions of the early help service are the following:

- educational outreach activity;

- organizational coordination activities;

- activities for the implementation of a comprehensive medical-psychological-pedagogical diagnosis;

- psychological and pedagogical counseling, assistance and rehabilitation activities;

- preventive activity;

- psycho-pedagogical information activities;

- development activities;

- medical advice and assistance;

- psychotherapeutic activity;

- methodical activity;

- scientific experimental activity;

- continuing education activities;

- activities to create and develop a team and interdisciplinary team of specialists;

- provision of material services needs activities [9].

\section{CONCLUSIONS}

Summing it up, it is necessary to emphasize once again the importance of creating early help services based on preschool educational institutions in the context of the implementation of a socio-pedagogical approach (to create conditions for successful positive socialization of disabled children, children with limited abilities and their families). This, in turn, should lead to such results as:

- positive dynamics in the child's development, which is determined by the qualitative assessment of the control parameters (indicators) of development, such as general motor skills, sensory development, development of spatial concepts, formation of subject-game actions, speech development, communicative development, emotional development;

- positive dynamics of family adaptation to the problems of child development and health, which is determined by the qualitative assessment of the following control parameters (indicators): initiating the child's development process, creating a home developing environment, systematicity, involvement in classes, following the recommendations of specialists, consistency of parents' actions, independent tracking of child development.

\section{References}

[1] T.R. Tenkacheva, L.Tokarskaya, A.V. Kostyuk, S.O. Bryzgalova, "Learning of coherent speech of pre-school age children with mental retardation", The European Proceedings of Social \& Behavioura Sciences, pp. 133-139, May 2018 [VII International Conference Early Childhood Care and Education, 2018]

[2] V.S. Torokhtiy, "Socio-pedagogical approach to the activities of educational institutions", Electronic scientific and educational journal of VGSPU «Grany poznaniya», vol. 2(29), pp. 62-70, 2014.

[3] Yu. A.Verkhoturova, Yu. N. Galaguzova, E. V. Dongauzer, "Destructive interaction of parents with early aged children in well-off families", The European Proceedings of Social \& Behavioural Sciences, pp. 164-171, May 2018 [VII International Conference Early Childhood Care and Education, 2018].

[4] S. Shabas. "The influence of the family on the child's normative development in preschoolers", The European Proceedings of Social \& Behavioural Sciences, pp. 127-132, May 2018 [VII International Conference Early Childhood Care and Education, 2018].

[5] V. Solondaev, E. Koneva. "Behavioural correlates of child-mother attachment in preschool and primary school children", The European Proceedings of Social \& Behavioural Sciences, pp. 287-294, May 2018 [VII International Conference Early Childhood Care and Education, 2018].

[6] E.V. Zinovieva, T.V. Kazantseva, A.N. Pleshkova, S.N. Kostromina, "The quality of paternal relationship in modern Russia", The European Proceedings of Social \& Behavioural Sciences, pp. 287-294, May 2018 [VII International Conference Early Childhood Care and Education, 2018]

[7] M.L. Worlach, R.H. Gurwitch, M.B. Bruder, L.A. Knight, "The role of comprehensive interdisciplinary assessment in early intervention system", The Developmental Systems Approach to Early Intervention. Baltimore: Paul H. Brookes Publishing Co, 2005, pp. 133-150.

[8] L.I. Aksenova, Early help for children with disabilities. Moscow: Yurayt, 2018, p. 12

[9] Yu.A. Razenkova, "Organization of service/department of early care", Early psychological and pedagogical assistance to families and children with disabilities. Moscow: Agency for Strategic Initiatives, 2015, pp. 1327.

[10] L.B. Astakhova, "Implementation of a family-centered approach in the process of speech therapy support for children of early and preschool age and their parents", Pedagogical education in Russia, vol. 4, pp. 113119,2018

[11] N.N. Malofeev. "Strategy of modernization of the Russian system of special education - early start and proper organization of psychological and pedagogical assistance", Early help for children: problems, facts, comments. Moscow: Human rights, 2003, pp. 68-77.

[12] L.V. Samarina, Erly aid Service: guidelines for managers and specialists Yekaterinburg, 2019.

[13] Support for a troubled child and his / her family in the early care system. Diagnosis and correction of development, In Y.A. Razenkova (Ed.). Moscow: School Press, 2012.

[14] G.I. Gysin, "Socio-pedagogical approach in pedagogical research informative characteristics and principles of implementation", Kazan Pedagogical Journal, vol. 4, pp. 10-15, 2017.

[15] V.M. Polonsky, Large thematic dictionary on education and pedagogy. Moscow: Public Education, 2017, p. 125.

[16] T.S. Dorokhova, M.A. Galaguzova, I.V. Volgina, "Socio-pedagogical Support for Children with Special Educational Needs at Pre-school Education Institution", The European Proceedings of Social \& Behavioural Sciences, pp. 22-27, May 2018 [VII International Conference Early Childhood Care and Education, 2018].

[17] Yu.N. Galaguzova, E.V. Dongauser, N.I. Mazurchuk, Socio-pedagogical activity in educational organizations. Yekaterinburg: Publishing UrGPU, 2017 , p. 17 